June 2003 • NREL/TP-550-33411

\title{
NREL Wind Site Entrance Building: Design Review and Recommendations
}

R. Ault, P. Torcellini, and O. Van Geet

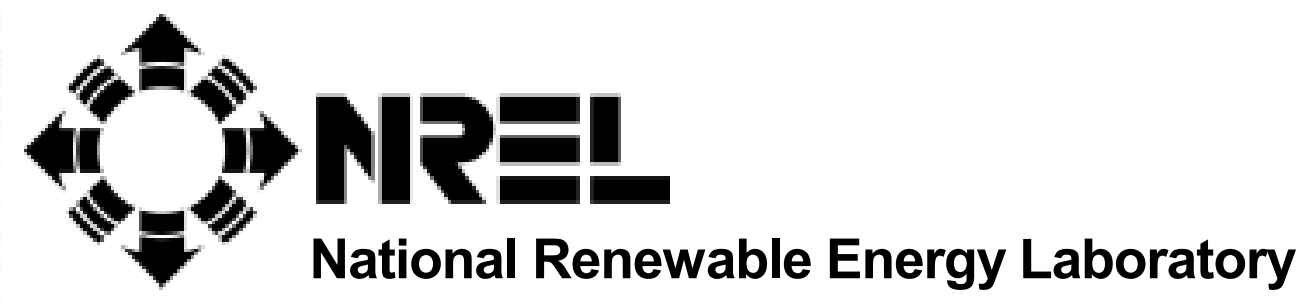

1617 Cole Boulevard

Golden, Colorado 80401-3393

NREL is a U.S. Department of Energy Laboratory

Operated by Midwest Research Institute • Battelle • Bechtel

Contract No. DE-AC36-99-G010337 


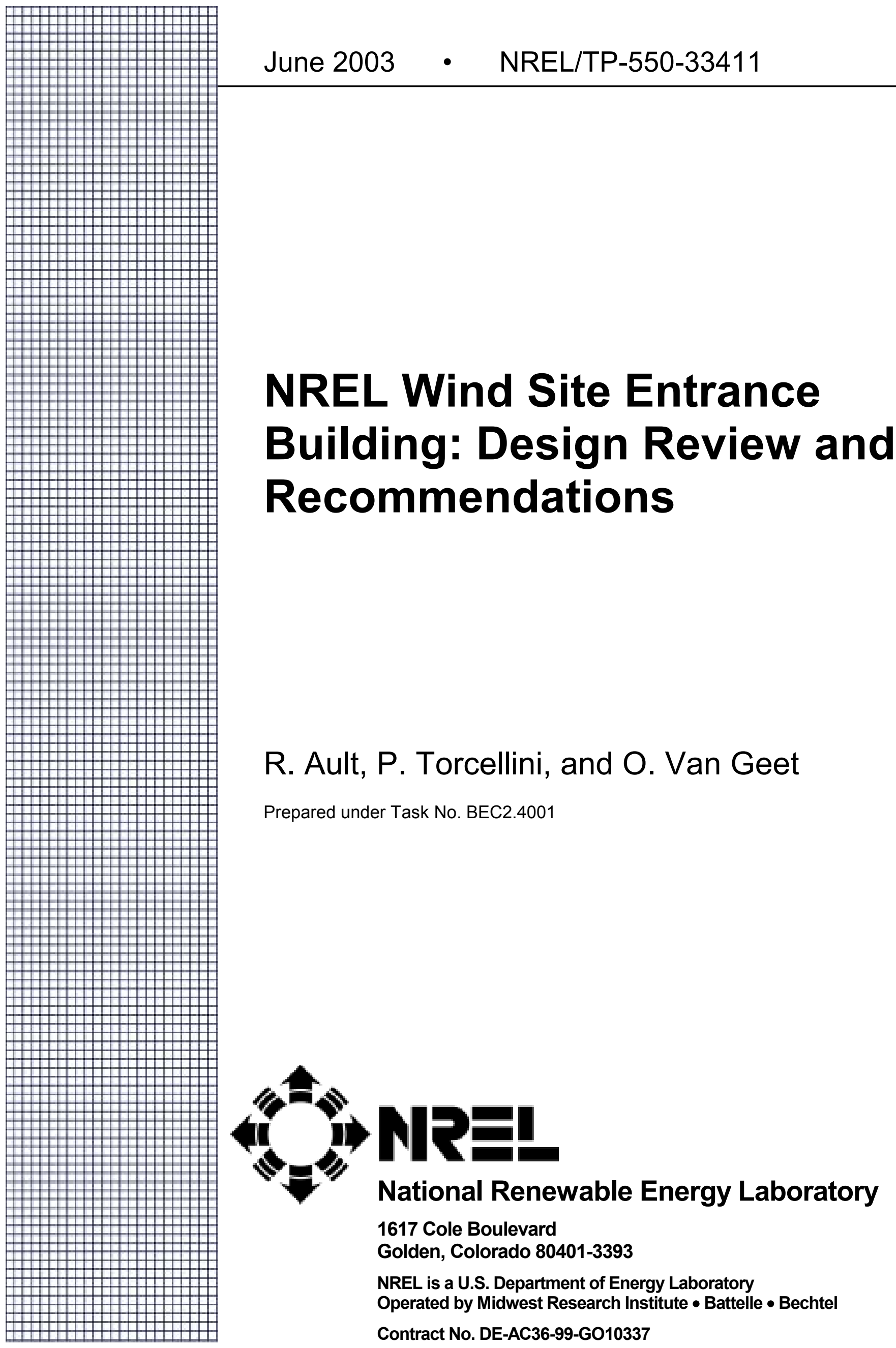




\section{NOTICE}

This report was prepared as an account of work sponsored by an agency of the United States government. Neither the United States government nor any agency thereof, nor any of their employees, makes any warranty, express or implied, or assumes any legal liability or responsibility for the accuracy, completeness, or usefulness of any information, apparatus, product, or process disclosed, or represents that its use would not infringe privately owned rights. Reference herein to any specific commercial product, process, or service by trade name, trademark, manufacturer, or otherwise does not necessarily constitute or imply its endorsement, recommendation, or favoring by the United States government or any agency thereof. The views and opinions of authors expressed herein do not necessarily state or reflect those of the United States government or any agency thereof.

Available electronically at http://www.osti.gov/bridge

Available for a processing fee to U.S. Department of Energy and its contractors, in paper, from:

U.S. Department of Energy

Office of Scientific and Technical Information

P.O. Box 62

Oak Ridge, TN 37831-0062

phone: 865.576 .8401

fax: 865.576.5728

email: reports@adonis.osti.gov

Available for sale to the public, in paper, from:

U.S. Department of Commerce

National Technical Information Service

5285 Port Royal Road

Springfield, VA 22161

phone: 800.553.6847

fax: 703.605.6900

email: orders@ntis.fedworld.gov

online ordering: http://www.ntis.gov/ordering.htm 


\section{Acknowledgments}

The authors would like to thank the following people who reviewed this report: Sue Budden (NREL Security); Michael Deru, and Ron Judkoff (NREL Center for Buildings and Thermal Systems); Dru Crawley (U.S. Department of Energy's Office of Building Technology); Nadav Malin (BuildingGreen, Inc.) and Tom Wood (School of Architecture, Montana State University). The authors would also like to thank NREL facilities, in particular the architect, Casey Morse, for integrating the design concepts and making this project possible. 


\section{TABLE OF CONTENTS}

Acknowledgments

Executive Summary ………………................................................................................................... 1

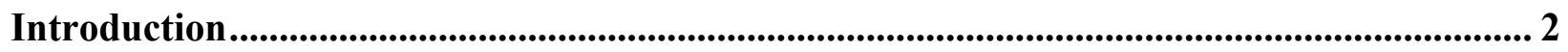

NREL Wind Site Entrance Building ........................................................................................... 2

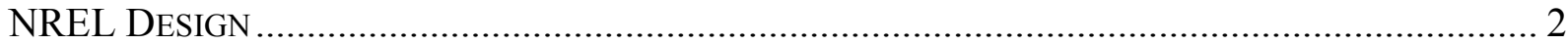

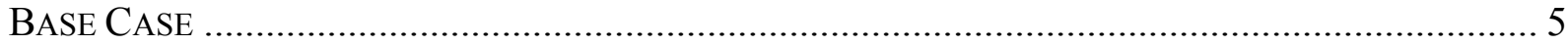

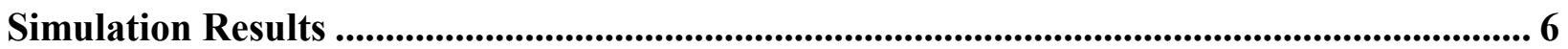

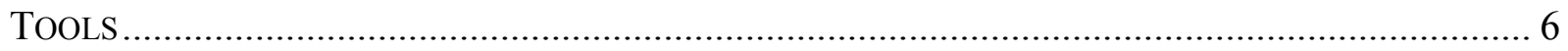

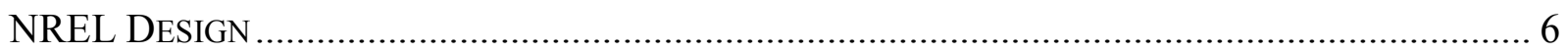

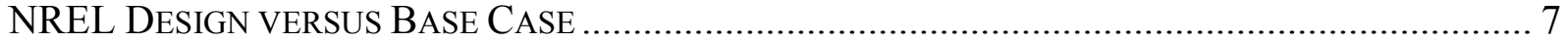

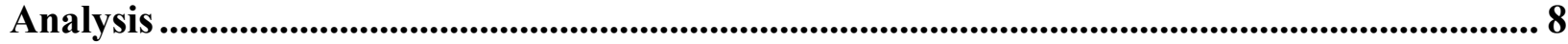

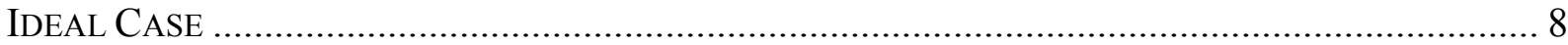

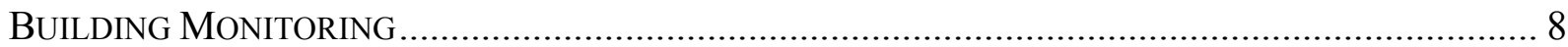

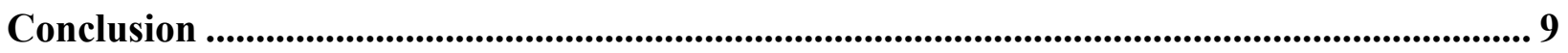

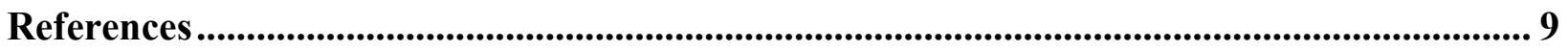

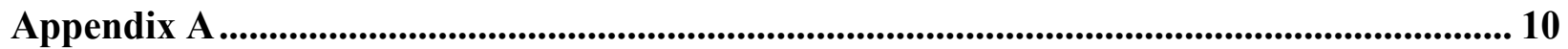

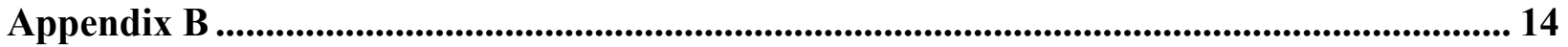




\section{Executive Summary}

By incorporating renewable and energy-efficient technologies from the beginning of the design process, NREL was able to design a building that has the potential to export more energy than it consumes for the same construction costs as a conventional building. The Wind Site Entrance Building design includes a Trombe wall, daylighting, energy-efficient appliances, high-mass walls, good thermal envelope, low-e windows, and integrated photovoltaic panels. The entire building was designed as a package using hourly energy simulations to determine the orientation, glass amounts and type, overhang length, and the parameters of the Trombe wall.

Although small, the building is representative of many guard facilities, remote restrooms, and outposts. The technologies used can easily be scaled up to create single-story buildings for retail, office spaces, visitor centers and contact stations. In addition, the high value placed on simplicity in the design of the building avoids complicated control schemes such that the building can be reproduced economically for a variety of applications.

The predicted energy performance of the building shows an overall energy consumption of $70.26-\mathrm{kBTU} / \mathrm{ft}^{2} /$ year with $80 \%$ of this value being for equipment loads. The integrated $\mathrm{PV}$ system is projected to provide $24.03 \mathrm{kBTU} / \mathrm{ft}^{2}$ or $1127 \mathrm{kWh}$ per year to the building. Additional renewable energy in the form of wind energy has been integrated into the building design. The building will be monitored in the future to compare the actual energy performance with the predicted performance. 


\section{Introduction}

The National Renewable Energy Laboratory's Security Force is in need of a small Site Entrance Building (SEB) or guard post to be located at the NREL Wind Site along the existing access road near the current operable gates. Currently, a 4-kW power line from the existing power grid runs to this location and powers the gates. This small power line cannot supply the electricity required by a conventional site entrance building. For this reason, a $20-\mathrm{kW}$ power line would need to be installed, drastically increasing the expense of the project. This project provides the opportunity to show that a small commercial building can be constructed using energy-efficient and renewable energy technologies at a similar or lower cost than conventional construction. This building could become the first NREL building to provide more power to the grid than it consumes.

The purpose of this report is to discuss the results of a computer simulation performed for the design of the SEB. The report details the expected performance of the building and defines a benchmark base-case building.

\section{NREL Wind Site Entrance Building}

\section{NREL Design}

The SEB for the Wind Site is to be a high-performance building that draws little energy from the power grid. It will house two desks and related computers such that personnel can work at their desks while the site entrance is monitored. The only utility currently available to the site is a 4$\mathrm{kW}$ power line currently being used to operate the existing security gates and security light. In addition, the building must be able to withstand the area's severe winds.

The energy features of the building were designed with SUNREL [1]. A study was done to determine the appropriate thermal characteristics including glazing type, overhang length, insulation amounts, and sizing of the heat pump.

The energy features of the building are:

- Optimal building orientation. An elongated east-west axis maximizes solar gain. (The building footprint measures 16 feet by 10 feet.)

- Daylighting. The glass used in the windows has a visible transmittance of 0.45 . North daylighting glass has a glass area of $15.25 \mathrm{ft}^{2}$ and is $10 \mathrm{ft}$ off the floor. The south daylighting glass is $28.5 \mathrm{ft}^{2}$, has a visible transmittance of 0.58 , and a solar heat-gain coefficient of 0.57 . The total area of the daylighting glass is $27 \%$ of the floor area.

- Operable windows. One-third of the north daylighting glass is operable as are view windows on each façade. Together, these windows provide for effective natural ventilation.

- Energy-efficient lighting. Electric lighting is provided using T-8 dimming fluorescent fixtures with an installed watt density of $0.75 \mathrm{~W} / \mathrm{ft}^{2}$. An occupancy sensor with daylighting control turns off the lights when no motion is detected or sufficient daylighting is available. 
- Efficient computers and appliances. Laptop computers and flat screen monitors were specified to reduce plug loads. The rating on this equipment is $20 \mathrm{~W}$ when the equipment is operating. A low-wattage refrigerator was also specified with an average daily consumption of $0.16 \mathrm{kWh}$.

- Trombe wall. A Trombe wall with an area of $44 \mathrm{ft}^{2}$ is used. The Trombe wall has a single piece of low-iron patterned glass installed on a thermally broken storefront system. The Trombe wall is 4 inches thick concrete.

- Window overhang. An overhang of $1.58 \mathrm{ft}$ was designed into the roof to shade the $9-\mathrm{ft}$ high wall from solar gains in the summer.

- Efficient windows. The roof is south-facing and angled at $24^{\circ}$ to accommodate a $768-\mathrm{W}$ photovoltaic (PV) array. The south glass on the building has a solar heat-gain coefficient of 0.57 to allow for passive solar gains in the winter. The area of this glass adds another $15 \mathrm{ft}^{2}$ to the south glass area. The east and west view windows have a solar heat-gain coefficient of 0.29 to block unwanted solar gains. All lower windows have lowemmissivity blinds to control gain and minimize heat loss.

- Photovoltaic system. The roof is south-facing and angled at $24^{\circ}$ from horizontal to accommodate a 768-W photovoltaic (PV) array. The building's PV system is an integral part of the uninterruptible power supply (UPS). This UPS consists of 12 Uni-Solar 64-W $\mathrm{PV}$ panels yielding a total of $768 \mathrm{~W}$. The panels are connected to a Trace DC-AC inverter, and to 4 Trojan 30XHS, deep-cycle, 130Ah batteries. The electrical system for this building is designed to accommodate future upgrades, including conduit to the locations where additional PV arrays and wind turbines could be installed. This system will be effective in providing renewable energy to the building under everyday operation, and also during occasional power outages. An electrical system schematic for the building can be found in Appendix A. Batteries and an inverter in the building supply UPS power to the lights and computer equipment in the event of a power outage. Heating and cooling, as well as the refrigerator, are not connected to the UPS system.

- Efficient heating and cooling. A heat pump was sized based on the hourly energy simulation. This unit is rated to provide $10,500 \mathrm{Btu} / \mathrm{h}$ for heating and $8,800 \mathrm{Btu} / \mathrm{h}$ for cooling with a heating and cooling COP of 3.5. The floor-area normalized values for heating and cooling design conditions are $55 \mathrm{BTU} / \mathrm{h} \cdot \mathrm{ft}^{2}$ and $65.6 \mathrm{BTU} / \mathrm{h} \cdot \mathrm{ft}^{2}(218 \mathrm{ft} / \mathrm{ton})$, respectively. No electric resistance heating is used in the building.

- High-mass building. The building is 4" tilt-up concrete for the walls with a 4" slab for the floor. The floor slab is insulated with 2" of rigid insulation for an R-value of 10. The walls have an EIFS (Exterior insulating finishing system). The 5 inches of exterior foam have an R-value of 25. The roof is composed of a structural insulated panel (SIP) with a total R-value of 30 . The thermal integrity of the building was closely monitored during construction.

- Minimized building controls. A lockout on heating occurs when the exterior temperature exceeds $55^{\circ} \mathrm{F}$. Cooling lockout occurs when the outdoor temperature drops below $75^{\circ} \mathrm{F}$. A motion sensor controls a setback temperature of $60^{\circ} \mathrm{F}$ and disables the cooling. 


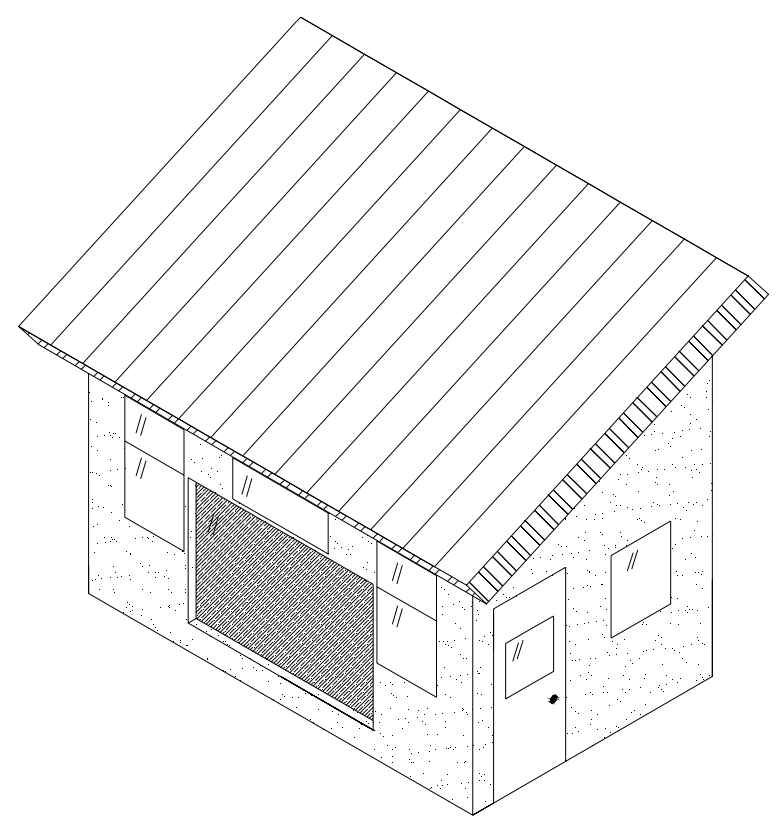

Figure 1. SEB design with southward facing Trombe wall and daylighting windows, shade control overhangs, and angled roof for PV installation.

The current budget for the construction of the SEB is $\$ 164,933.62$. The details of this budget are seen in Table 1.

Table 1 - SEB Budget

\begin{tabular}{|l|r|r|}
\hline Work Activity Description & \multicolumn{1}{|c|}{ Materials } & \multicolumn{1}{l|}{ Labor } \\
\hline Project Manager & & $\$ 9,694.80$ \\
\hline Field Supervisor & & $\$ 9,234.00$ \\
\hline Cleanup \& Protection & $\$ 8,025.52$ & \\
\hline Earthwork \& Concrete On Site & $\$ 6,575.00$ & \\
\hline Boulders & $\$ 2,014.00$ & \\
\hline Fence Work and Seeding & $\$ 12,712.00$ & \\
\hline Concrete Pre-cast & $\$ 1,762.00$ & \\
\hline Insulated Structural Panels & $\$ 22,500.00$ & \\
\hline Metal Roof and Solar & $\$ 21,000.00$ & \\
\hline EIFS System & $\$ 3,282.00$ & $\$ 4,079.28$ \\
\hline Carpentry & $\$ 8,751.00$ & \\
\hline Glazing & $\$ 245.00$ & $\$ 2,284.80$ \\
\hline Painting & $\$ 4,229.00$ & \\
\hline Mechanical & $\$ 18,649.00$ & \\
\hline Electrical & & \\
\hline & $\$ 109,894.52$ & $\$ 28,568.88$ \\
\hline Subtotal & $\$ 10,989.45$ & \\
\hline MCDS Overhead $10 \%$ & $\$ 12,088.40$ & \\
\hline MCDS Profit $10 \%$ & $\$ 132,972.37$ & $\$ 28,568.88$ \\
\hline Subtotals & & \\
\hline
\end{tabular}




\begin{tabular}{|c|c|}
\hline MCDS Bond & $\$ 3392.37$ \\
\hline Total Firm Fixed Price & $\$ 164,933.62$ \\
\hline
\end{tabular}

\section{Base Case}

To determine the energy and cost savings derived from the integration of the many energy conservation technologies, a base case model was developed. The model was designed to satisfy the Federal Energy Code 10CFR434, which is based on ASHRAE Standard 90.1-2001. Table 2 shows some of the parameters used for the base case.

Table 2 - Base-Case Parameters

\begin{tabular}{|l|c|}
\hline \multicolumn{1}{|c|}{ Item } & Value \\
\hline Wall R-Value $\left(\mathrm{ft} \cdot{ }^{\circ} \mathrm{F} \cdot \mathrm{hr} / \mathrm{Btu}\right)$ & 7.6 \\
\hline Lighting Energy Flux $\left(\mathrm{W} / \mathrm{ft}^{2}\right)$ & 1.3 \\
\hline Window U-Value $\left(\mathrm{Btu} / \mathrm{ft} \cdot{ }^{\circ} \mathrm{F} \cdot \mathrm{hr}\right)$ & 0.57 \\
\hline Window SC & 0.67 \\
\hline Roof R-Value $\left(\mathrm{ft} \cdot{ }^{\circ} \mathrm{F} \cdot \mathrm{hr} / \mathrm{Btu}\right)$ & 15 \\
\hline
\end{tabular}

Table 3 shows a list of the internal thermal loads from which the sensible and latent heating load schedule for the base case was derived.

Table 3 - Internal Heating Loads

\begin{tabular}{|l|c|c|c|c|}
\hline \multirow{2}{*}{ Item } & \multicolumn{2}{|c|}{ Sensible Load } & Latent Load & \multirow{2}{*}{ Time } \\
\cline { 2 - 4 } & $\mathrm{W}$ & $\mathrm{kBtu} / \mathrm{h}$ & $\mathrm{kBtu} / \mathrm{h}$ & \\
\hline Plug Loads & 500 & 1.71 & & 6 a.m. to 6 p.m. \\
\hline & 200 & 0.68 & & 6 p.m. to 6 a.m. \\
\hline Lights & 160.2 & 0.55 & & 6 a.m. to 6 p.m. \\
\hline People (1) & & 0.25 & 0.15 & 6 a.m. to 6 p.m. \\
\hline
\end{tabular}

It is approximated that the base-case plug power would be $500 \mathrm{~W}$ during the day, and $200 \mathrm{~W}$ at night. This load includes two computers, each with standard type monitors, a coffee pot, refrigerator, and other typical office devices.

The cost of building the base case would be less than the low energy design. The uninterruptible power supply (UPS), high performance windows, and insulating materials are some of the more expensive features of constructing a low energy building. However, this cost difference is more than offset by the dollars saved by not running a $20-\mathrm{kW}$ power line to the site. The estimated cost of the base case building including the new power line was $\$ 200,000$. Note that the UPS system is an added amenity to the building that was not included in the original building scope. 


\section{Simulation Results}

\section{Tools}

All thermal analysis was performed using the building energy analysis program SUNREL[1]. SUNREL is a thermal modeling program designed to simulate building loads dominated by solar and thermal storage. PV production and building electrical load simulations were done using PVSYST[2].

\section{NREL Design}

The results of the SUNREL and PVSYST simulations for the SEB are shown in Figure 2. From this figure, the building requires very little energy for the purposes of heating, cooling, and lighting. Most of the energy consumption is found in the equipment or plug loads (i.e., computers, monitors, and coffee pot).

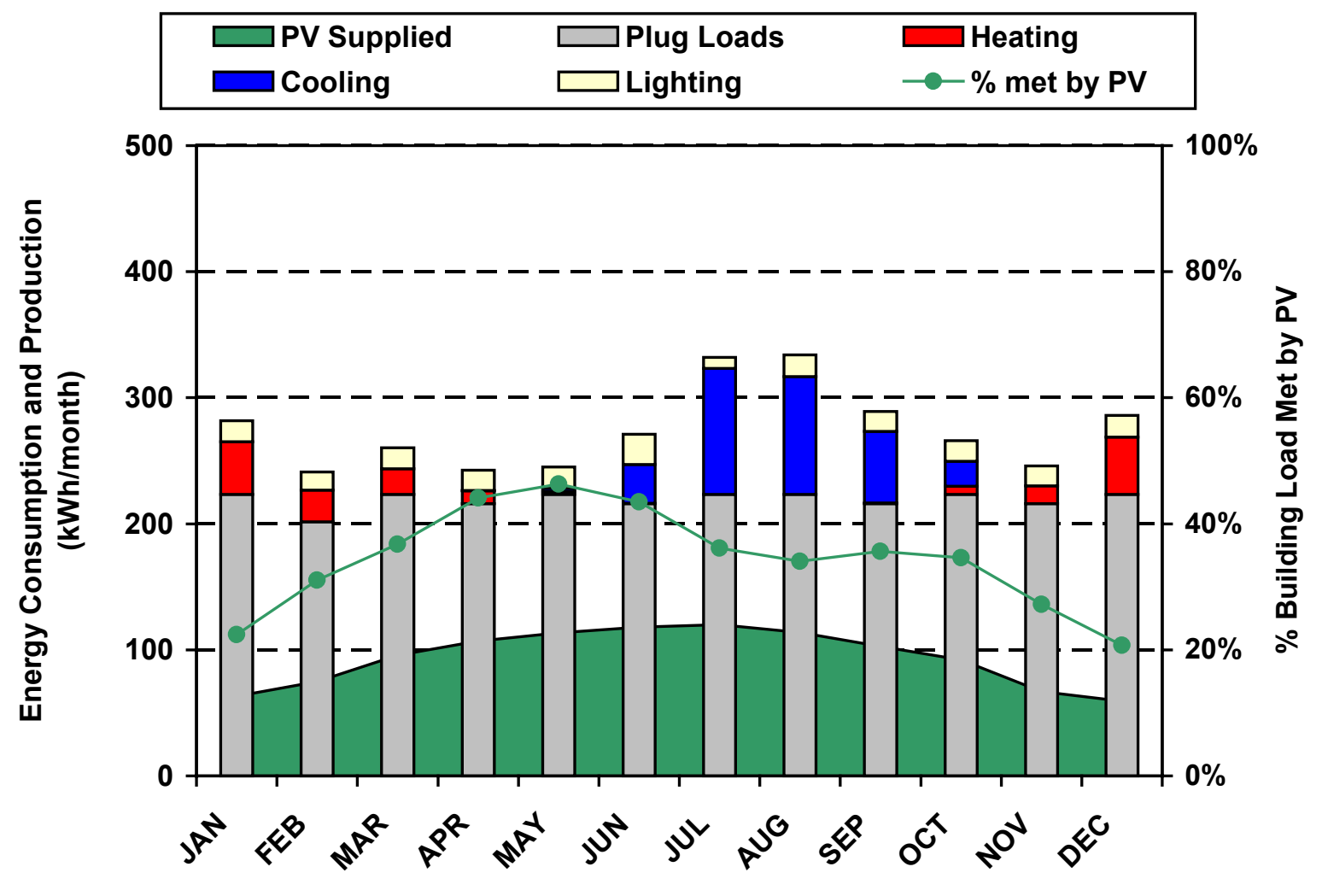

Figure 2. NREL Design Energy Performance Simulation Results

The above graph also shows the amount of energy produced by the PV array. Between $20 \%$ and $50 \%$ of the building's required energy is met by the PV system each month. With the expansion goals for the UPS to someday include additional PV and wind energy, it appears the SEB could potentially become a net energy producing building. 


\section{NREL Design versus Base Case}

As expected, the NREL design for the SEB outperforms the base-case model. Figure 3 breaks down the total energy consumption for the base case building, and Figure 4 shows the difference between the high-performance design and the base case. Table B-3 provides the annual summary data used for this analysis.

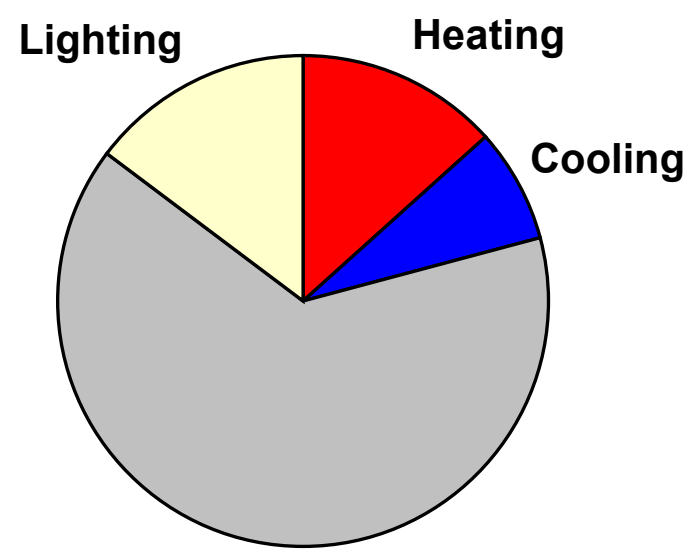

\section{Plug Loads}

Figure 3. Breakdown of Energy Consumption for Base Case

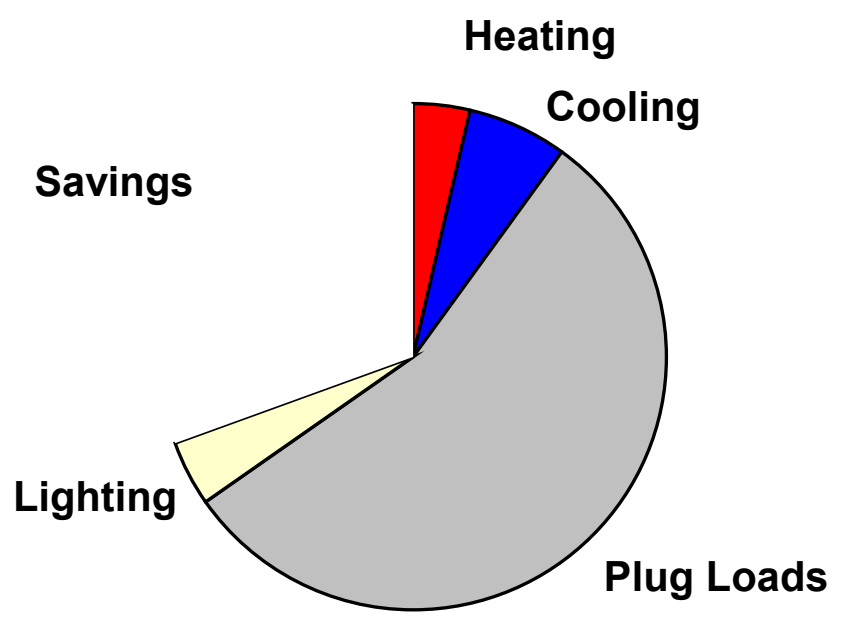

Figure 4. Energy Consumption Reduction from Base Case 
Without introducing the power produced by the PV array, the NREL building design exhibits a $30 \%$ energy savings over the base-case model. If the plug loads are ignored, and only heating, cooling, and lighting loads are compared, the NREL design yields a $60.5 \%$ savings. Including the addition of the array, the applied design will save about $54 \%$ off of the electric bill. Assuming \$0.054/kWh, this is approximately \$118 saved per year. Integration of energyefficiency and renewable technologies significantly reduce the energy demand in the areas of HVAC and lighting. The plug loads, which are most difficult to control, dominate the power demand for this particular building. This translates to an energy consumption of 70.26 $\mathrm{kBTU} / \mathrm{ft}^{2} \cdot \mathrm{yr}$. The net grid energy consumption is $46.23 \mathrm{kBTU} / \mathrm{ft}^{2} \cdot \mathrm{yr}$, after accounting for the contribution from the PV system.

Appendix B breaks down the heat gains and losses for the two simulations. The SEB, on average, will require more cooling than heating. The energy consumption graph in Figure 4 confirms this conclusion.

For equipment sizing, the low-energy design allowed for the following reductions. Originally, a building this size would have required an electrical capacity of $3 \mathrm{~kW}$ for heating and $2.45 \mathrm{~kW}$ for cooling. After adding lighting and plug loads to this demand, the limit of the existing $4 \mathrm{~kW}$ line is exceeded. The initial estimate required a power line of $20 \mathrm{~kW}$ to meet this load. As a result of the improvements, the capacity of the building was reduced to $2.37 \mathrm{~kW}$ for heating and $2.14 \mathrm{~kW}$ for cooling, which with the help of renewable energy sources could be supplied by two 20-amp legs of the existing $4 \mathrm{~kW}$ power line.

\section{Analysis}

\section{Ideal Case}

Ideally, the SEB would be a net energy producer, generating more power than it consumes in one year. The building is clearly dominated by plug loads. Based on this load, the SEB would require wind turbines or additional PV panels to reach the net producing goal. In the current design, the PV system covers $150 \mathrm{ft}^{2}$ of the $257-\mathrm{ft}^{2}$ roof or $58 \%$ of the available roof area. To meet the estimated energy consumption of the building, about $1,500 \mathrm{~W}$ of PV array would need to be added to the exiting $768-\mathrm{W}$ array to produce the extra $2,000 \mathrm{kWh}$ needed each year. In order to accomplish this, the PV area would need to be tripled to $174 \%$ of the roof area. Therefore, assuming the plug load estimate is accurate, it is not possible for the roof area to supply all the needed energy for the building.

\section{Building Monitoring}

It is proposed to monitor the building so that actual performance can be compared with the simulated design analysis. Through this comparison, it will be possible to evaluate both the SUNREL software and the actual construction of the building. Below is a list of measurements necessary to effectively monitor the SEB for a comparison with the simulation.

1. Power supplied to building from grid

2. Power delivered to grid from building

3. Power consumed by heat pump 
4. Power produced by PV panels

5. Power supplied by batteries

6. Power consumed by external lighting

7. Power consumed by internal lighting

8. Power consumed by internal plug loads

9. Temperature inside building envelope

Logging this information will be useful in detecting discrepancies between the design and the actual construction of the SEB.

\section{Conclusion}

A new site entrance building has been designed for the NREL wind site that uses $30 \%$ less energy (including plug loads) than a conventional building built and cost $\$ 35,000$ less because no upgrade in electrical infrastructure was needed. The design of the building was driven by computer simulation to minimize energy and power consumption such that no additional infrastructure was needed. The PV system helped minimize the demand as well as provide a UPS system for the building. The building is expected to consume $70.26 \mathrm{kBTU} / \mathrm{ft}^{2} \cdot \mathrm{yr}$ with $80 \%$ of this being plug loads. The net consumption with the PV system is $46.23 \mathrm{kBTU} / \mathrm{ft}^{2} \cdot \mathrm{yr}$.

\section{References}

[1] Deru, M.P.; Judkoff, R.; Torcellini, P. (2002) SUNREL ${ }^{\mathrm{TM}}$ Technical Reference Manual. 140 p.p.; NREL Report No. BK-550-30193.

[2] Mermoud, A. (1996) PVSYST Version 3.2. User's Manual. PC software package for the study, sizing, simulation, and data analysis of complete PV systems. University of Geneva, University Center for the Study of Energy Problems, Switzerland. Website: www.pvsyst.com <http://www.pvsyst.com>. Last accessed: December 2002. 


\section{Appendix A}

\section{Building Plans}

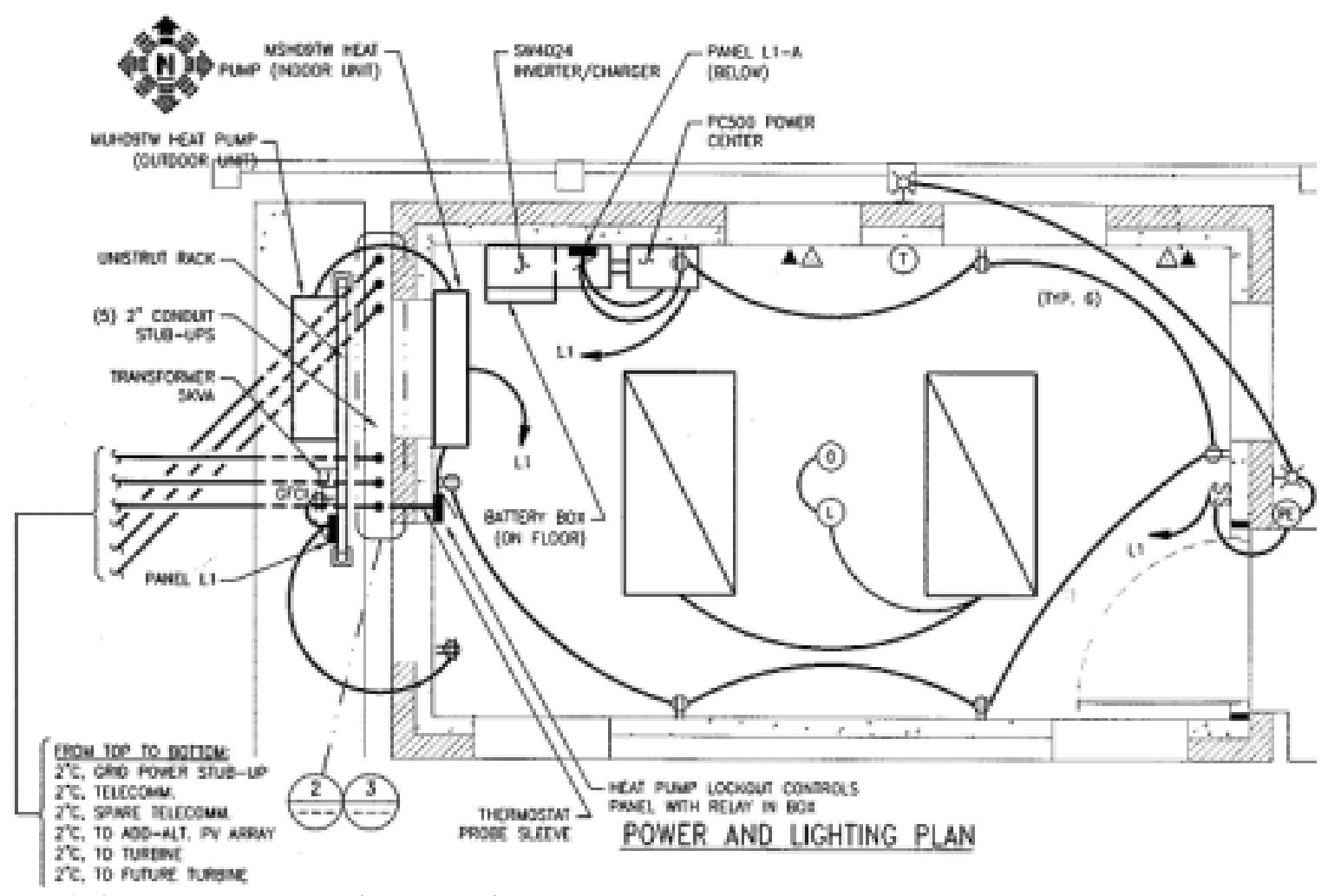

Figure A.1. Floor plan showing electrical layout.

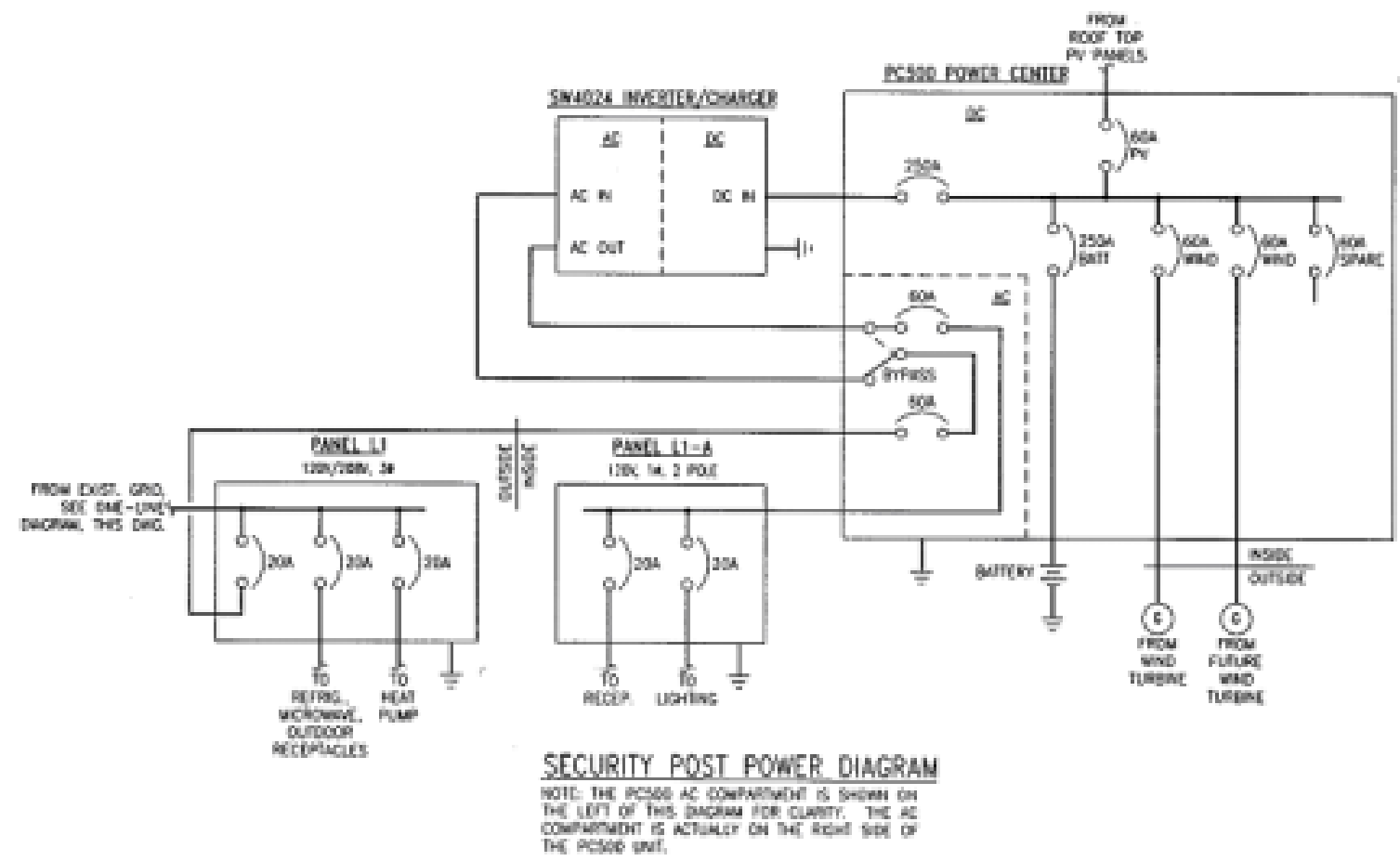

Figure A.2. Electrical distribution. 


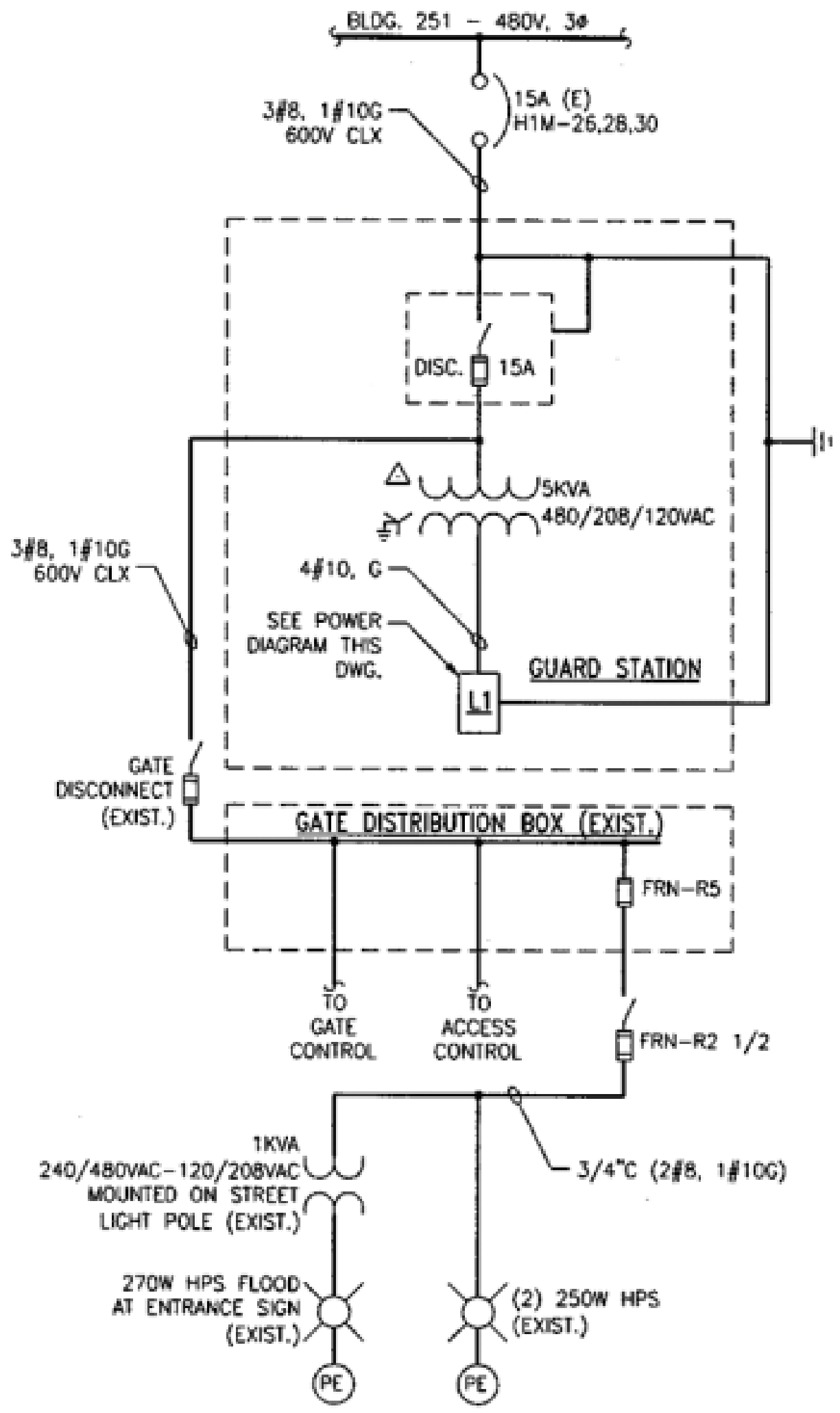

\section{ONE-LINE DIAGRAM}

Figure A.3. One-Line Diagram for electrical distribution system. 


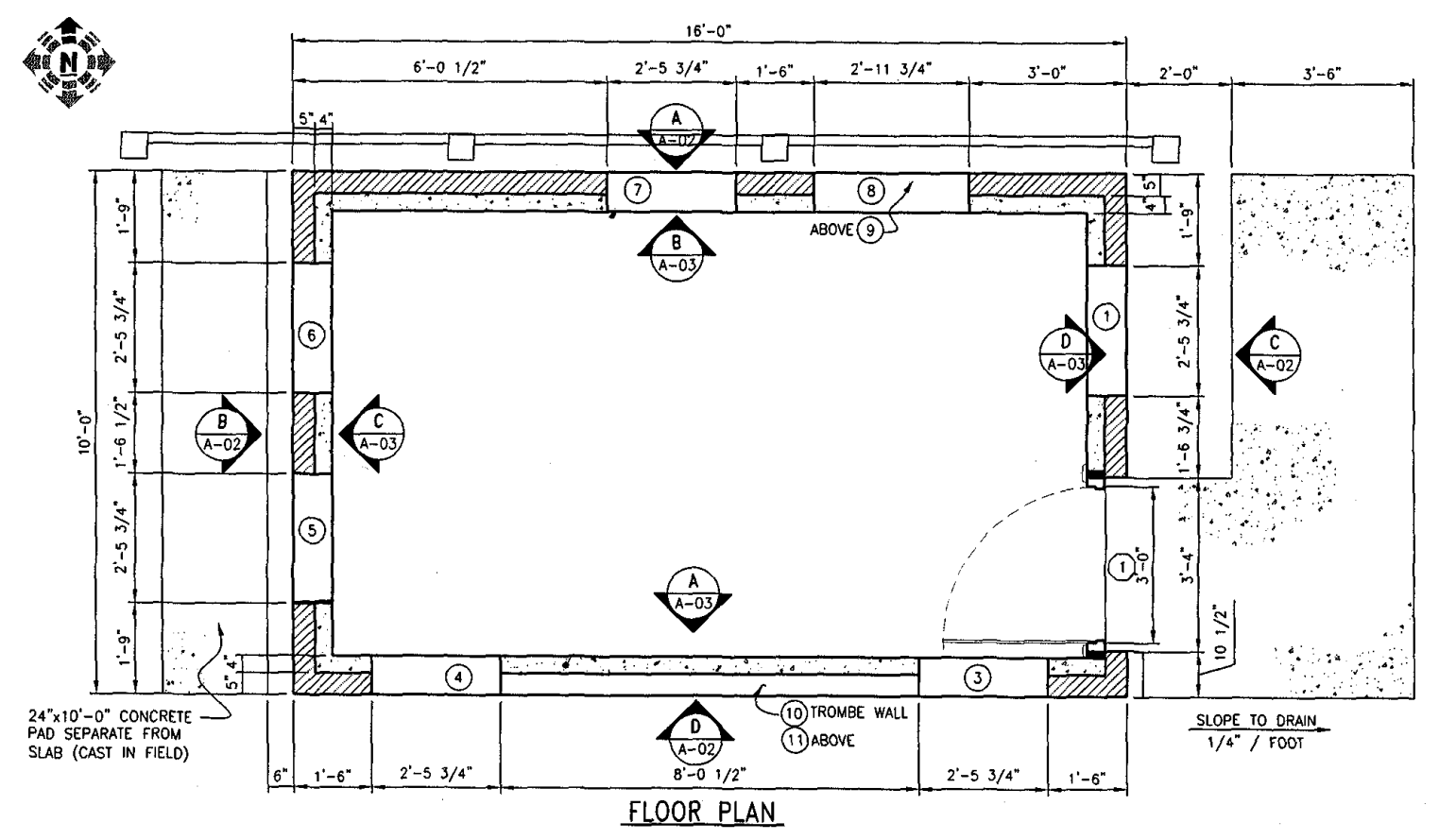

Figure A.4. Floor plan
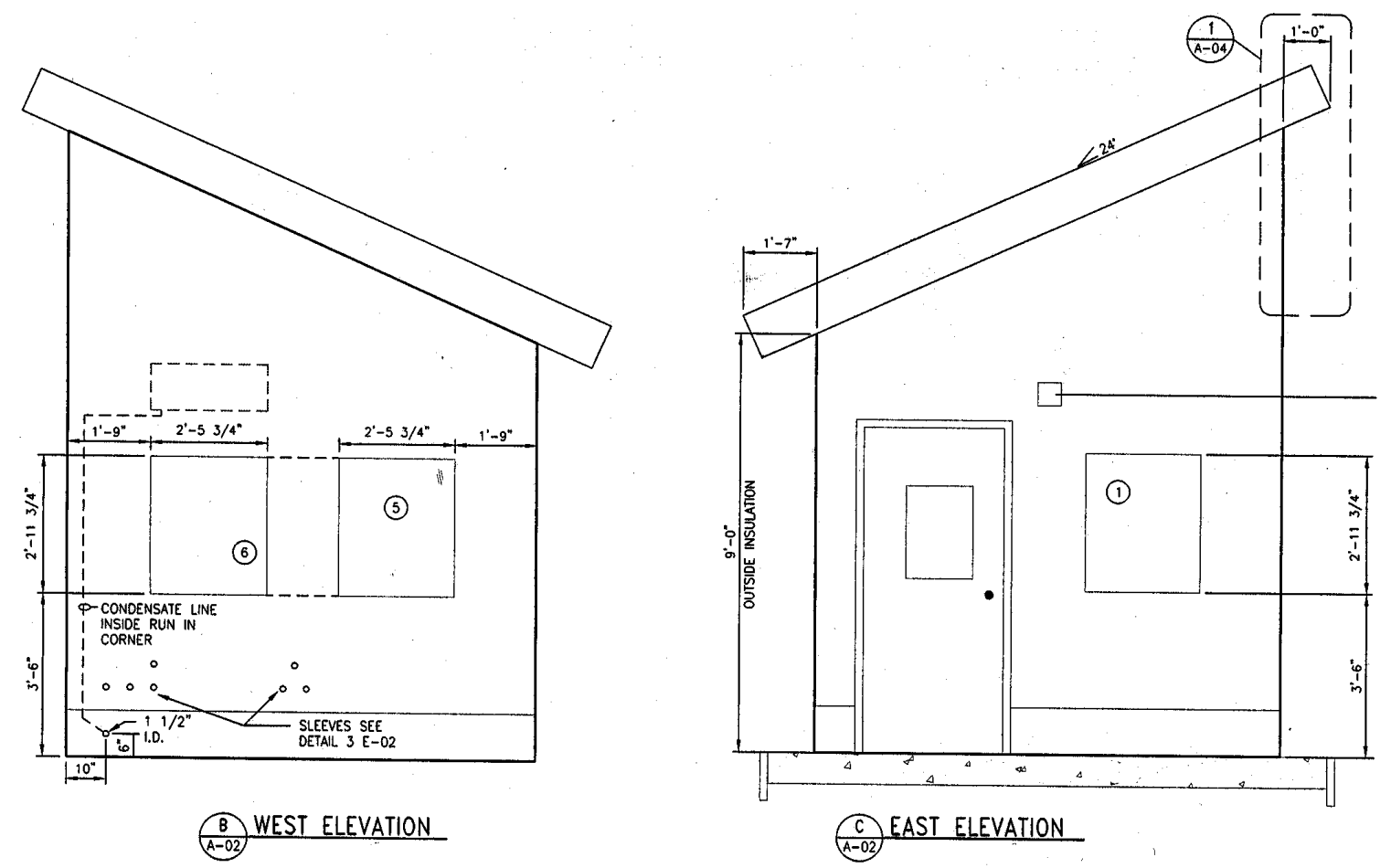

Figure A.5. West and east elevation profile 


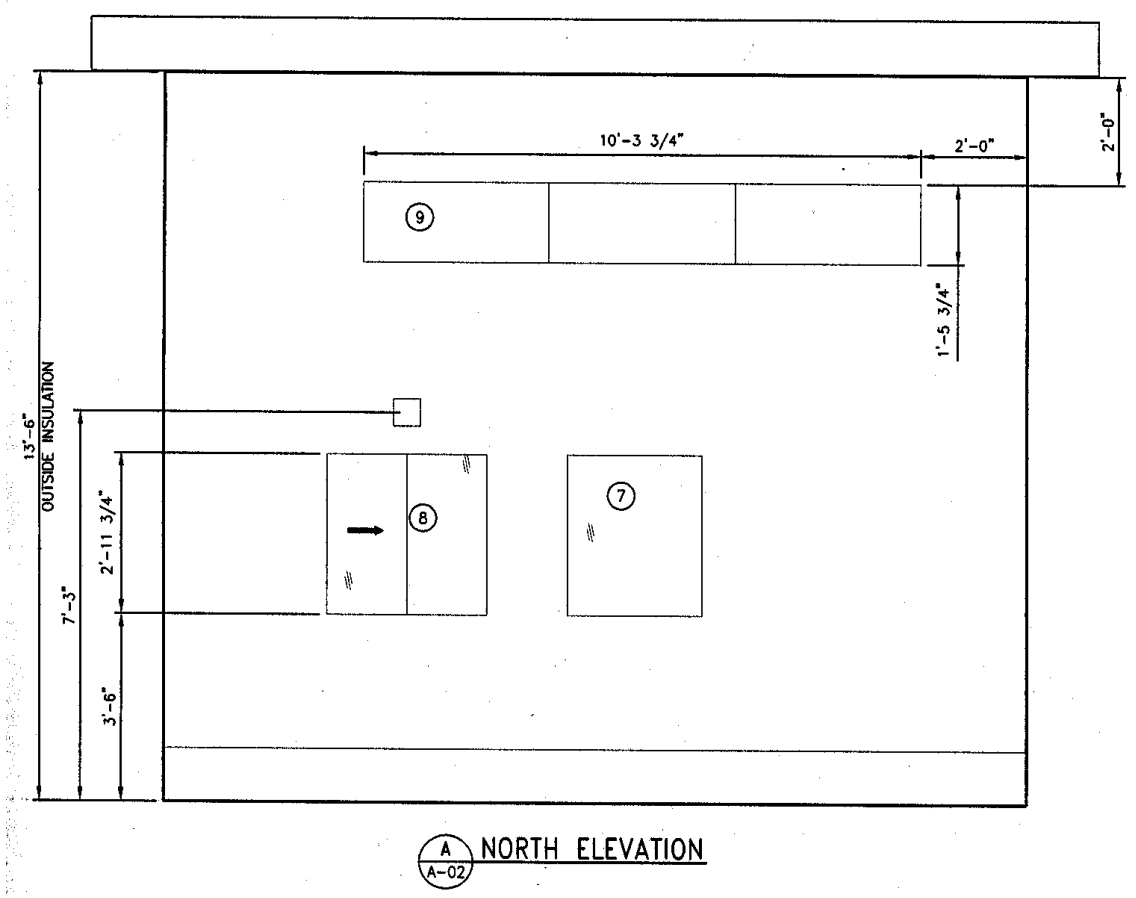

Figure A.6. North elevation profile

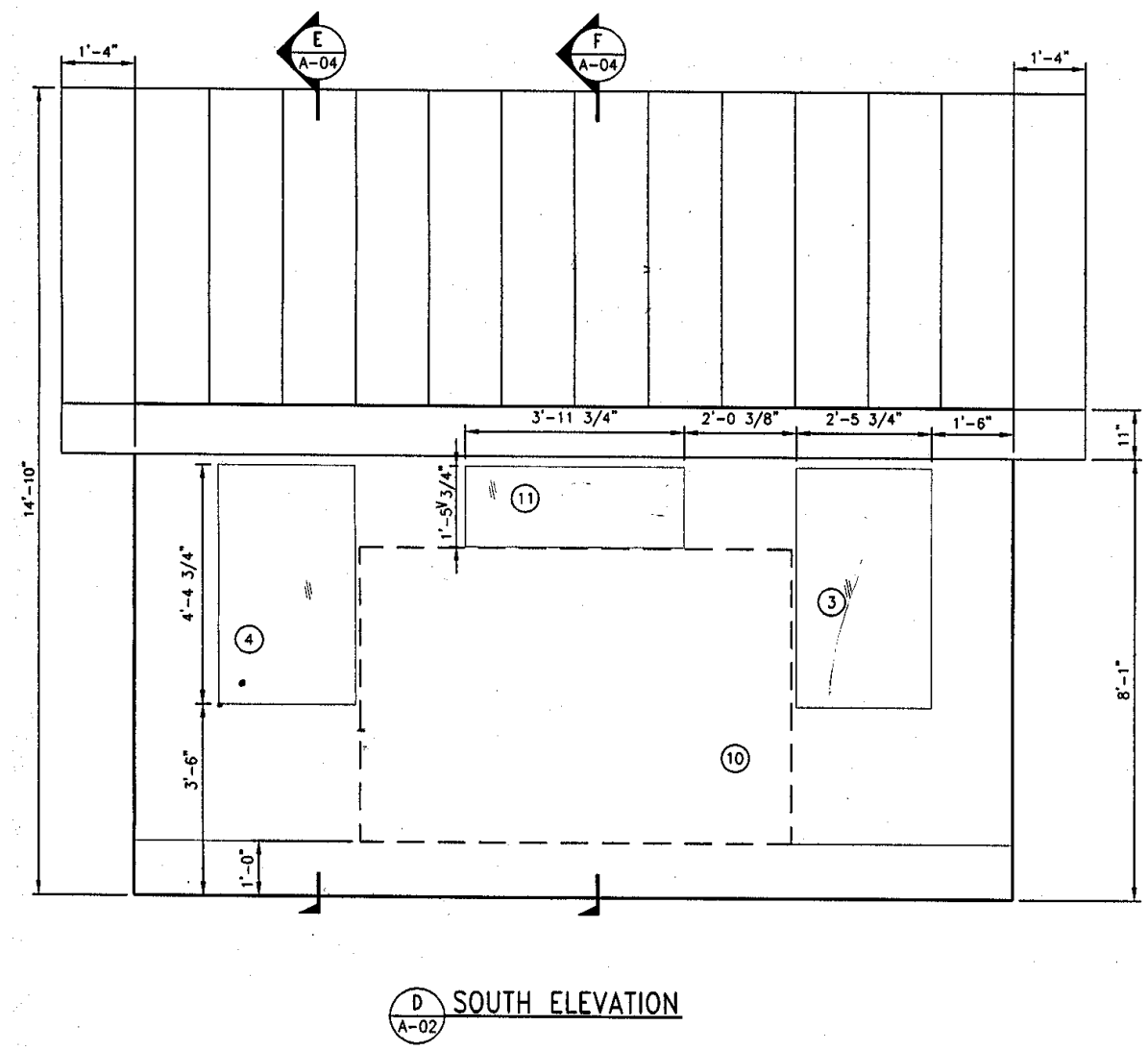

Figure A.7. South elevation profile 


\section{Appendix B}

\section{$\underline{\text { Simulation Results }}$}

Table B.1 - NREL Design Heat Gains and Losses

\begin{tabular}{|l|c|c|c|c|c|c|}
\hline & \multicolumn{3}{|c|}{ July } & \multicolumn{3}{c|}{ December } \\
\hline & $\begin{array}{c}\text { Heat Gain } \\
\text { MMBTU }\end{array}$ & $\begin{array}{c}\text { Heat Loss } \\
\text { MMBTU }\end{array}$ & $\begin{array}{c}\text { Net Heat } \\
\text { MMBTU }\end{array}$ & $\begin{array}{c}\text { Heat Gain } \\
\text { MMBTU }\end{array}$ & $\begin{array}{c}\text { Heat Loss } \\
\text { MMBTU }\end{array}$ & $\begin{array}{c}\text { Net Heat } \\
\text { MMBTU }\end{array}$ \\
\hline Roof & 0.009 & 0 & 0.009 & 0 & -0.191 & -0.191 \\
\hline Floor & & & & & & \\
Un-insulated & 0 & -0.017 & -0.017 & 0 & -0.154 & -0.154 \\
Insulated & 0 & -0.033 & -0.033 & 0 & -0.127 & -0.127 \\
\hline North Exposure & & & & & & \\
Window 1 & 0.016 & -0.002 & 0.014 & 0.006 & -0.041 & -0.035 \\
Window 2 & 0.082 & -0.004 & 0.078 & 0.028 & -0.077 & -0.049 \\
Window 3 & 0.034 & -0.006 & 0.028 & 0.011 & -0.101 & -0.09 \\
Wall & 0 & -0.009 & -0.009 & 0 & -0.204 & -0.204 \\
\hline South Exposure & & & & & & \\
Window 4 & 0.066 & -0.004 & 0.062 & 0.143 & -0.064 & 0.079 \\
Window 5 & 0.066 & -0.004 & 0.062 & 0.143 & -0.064 & 0.079 \\
Window 6 & 0.019 & -0.002 & 0.017 & 0.051 & -0.032 & 0.019 \\
Window 7 & 0.019 & -0.002 & 0.017 & 0.05 & -0.032 & 0.018 \\
Window 8 & 0.033 & -0.003 & 0.03 & 0.089 & -0.051 & 0.038 \\
Trombe Wall & 0.732 & -0.254 & 0.478 & 1.386 & -0.844 & 0.542 \\
Wall & 0 & -0.003 & -0.003 & 0 & -0.076 & -0.076 \\
\hline East Exposure & & & & & & \\
Window 11 & 0.044 & -0.003 & 0.041 & 0.015 & -0.049 & -0.034 \\
Window 12 & 0.114 & -0.003 & 0.111 & 0.041 & -0.046 & -0.005 \\
Wall & 0 & -0.001 & -0.001 & 0 & -0.091 & -0.091 \\
Door & 0.001 & 0 & 0.001 & 0 & -0.128 & -0.128 \\
\hline West Exposure & & & & & & \\
Window 9 & 0.031 & -0.003 & 0.028 & 0.015 & -0.049 & -0.034 \\
Window 10 & 0.031 & -0.003 & 0.028 & 0.015 & -0.049 & -0.034 \\
Wall & 0 & -0.003 & -0.003 & 0 & -0.106 & -0.106 \\
\hline Total & 1.297 & -0.359 & 0.938 & 1.993 & -2.576 & -0.583 \\
\hline
\end{tabular}


Table B.2 - Base-Case Heat Gains and Losses

\begin{tabular}{|l|c|c|c|c|c|c|}
\hline & \multicolumn{3}{|c|}{ July } & \multicolumn{3}{c|}{ December } \\
\hline & $\begin{array}{c}\text { Heat Gain } \\
\text { MMBTU }\end{array}$ & $\begin{array}{c}\text { Heat Loss } \\
\text { MMBTU }\end{array}$ & $\begin{array}{c}\text { Net Heat } \\
\text { MMBTU }\end{array}$ & $\begin{array}{c}\text { Heat Gain } \\
\text { MMBTU }\end{array}$ & $\begin{array}{c}\text { Heat Loss } \\
\text { MMBTU }\end{array}$ & $\begin{array}{c}\text { Net Heat } \\
\text { MMBTU }\end{array}$ \\
\hline Roof & 0 & -0.011 & -0.011 & 0 & -0.218 & -0.218 \\
\hline Floor & & & & & & \\
Un-insulated & 0 & -0.099 & -0.099 & 0 & -0.538 & -0.538 \\
North Exposure & & & & & & \\
Window 1 & 0.063 & -0.007 & 0.056 & 0.021 & -0.071 & -0.05 \\
Window 2 & 0.094 & -0.011 & 0.083 & 0.032 & -0.103 & -0.071 \\
Window 3 & 0.132 & -0.018 & 0.114 & 0.044 & -0.177 & -0.133 \\
Wall & 0 & -0.052 & -0.052 & 0 & -0.63 & -0.63 \\
\hline South Exposure & & & & & & \\
Window 4 & 0.096 & -0.009 & 0.087 & 0.157 & -0.085 & 0.072 \\
Window 5 & 0.096 & -0.009 & 0.087 & 0.157 & -0.085 & 0.072 \\
Window 6 & 0.038 & -0.004 & 0.034 & 0.062 & -0.042 & 0.02 \\
Window 7 & 0.038 & -0.004 & 0.034 & 0.062 & -0.042 & 0.02 \\
Window 8 & 0.066 & -0.007 & 0.059 & 0.108 & -0.068 & 0.04 \\
Wall & 0 & -0.027 & -0.027 & 0 & -0.371 & -0.371 \\
\hline East Exposure & & & & & & \\
Window 11 & 0.16 & -0.009 & 0.151 & 0.058 & -0.085 & -0.027 \\
Window 12 & 0.129 & -0.005 & 0.124 & 0.047 & -0.046 & 0.001 \\
Wall & 0 & -0.014 & -0.014 & 0 & -0.281 & -0.281 \\
Door & 0 & -0.011 & -0.011 & 0 & -0.218 & -0.218 \\
\hline West Exposure & & & & & & \\
Window 9 & 0.114 & -0.009 & 0.105 & 0.055 & -0.085 & -0.03 \\
Window 10 & 0.114 & -0.009 & 0.105 & 0.055 & -0.085 & -0.03 \\
Wall & 0 & -0.022 & -0.022 & 0 & -0.327 & -0.327 \\
\hline Total & 1.14 & -0.337 & 0.803 & 0.858 & -3.557 & -2.699 \\
\hline
\end{tabular}

Table B.3 - Base-Case and Design Annual Performance

\begin{tabular}{|ccccccc|}
\multicolumn{2}{c}{$\begin{array}{l}\text { Heating } \\
\text { kWh }\end{array}$} & $\begin{array}{l}\text { Cooling } \\
\text { kWh }\end{array}$ & $\begin{array}{l}\text { Plug } \\
\text { Loads } \\
\text { kWh }\end{array}$ & $\begin{array}{l}\text { Lighting } \\
\text { kWh }\end{array}$ & PV kWh & $\begin{array}{l}\text { Savings } \\
\text { kWh }\end{array}$ \\
Basecase & 637 & 347 & 3066 & 702 & 0 & 0 \\
Design & 167 & 304 & 2628 & 195 & 1127 & 1457
\end{tabular}




\section{REPORT DOCUMENTATION PAGE}

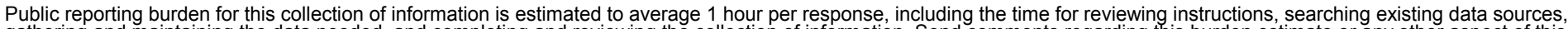

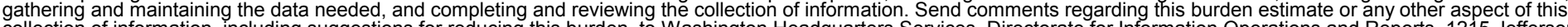

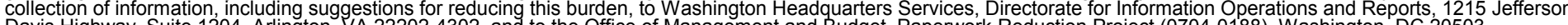

Davis Highway, Suite 1204, Arlington, VA 22202-4302, and to the Office of Management and Budget, Paperwork Reduction Project (0704-0188), Washington, DC 20503.
1. AGENCY USE ONLY (Leave blank)
2. REPORT DATE June 2003
3. REPORT TYPE AND DATES COVERED
Technical report
4. TITLE AND SUBTITLE
6. $\operatorname{AUTHOR}(\mathrm{S})$
R. Ault, P. Torcellini, and O. Van Geet
7. PERFORMING ORGANIZATION NAME(S) AND ADDRESS(ES)
National Renewable Energy Laboratory
1617 Cole Blvd.
Golden, CO 80401-3393

NREL Wind Site Entrance Building: Design Review and Recommendations

5. FUNDING NUMBERS

BEC3.4005

9. SPONSORING/MONITORING AGENCY NAME(S) AND ADDRESS(ES)

8. PERFORMING ORGANIZATION REPORT NUMBER

NREL/TP-550-33411

10. SPONSORING/MONITORING AGENCY REPORT NUMBER

11. SUPPLEMENTARY NOTES

12a. DISTRIBUTION/AVAILABILITY STATEMENT

National Technical Information Service

12b. DISTRIBUTION CODE

U.S. Department of Commerce

5285 Port Royal Road

Springfield, VA 22161

13. ABSTRACT (Maximum 200 words) Report giving review of the NREL Wind Site Guard Post Entrance building design and recommendations for improvement for greater energy savings and backup power.

14. SUBJECT TERMS Wind Site Entrance Building; building design; energy-efficient building features; energy efficiency; photovoltaics; passive solar design.

15. NUMBER OF PAGES

17. SECURITY CLASSIFICATION OF REPORT Unclassified
18. SECURITY CLASSIFICATION OF THIS PAGE Unclassified
19. SECURITY CLASSIFICATION OF ABSTRACT Unclassified
16. PRICE CODE

20. LIMITATION OF ABSTRACT

UL 